\title{
Colophons by the Tōdaiji Monk Sōshō (1202-1278): The Threshold between Text and Paratext
}

\author{
ASUKA SANGO \\ Carleton College \\ asango@carleton.edu
}

Abstract: Scholar monks of medieval Japan produced a vast body of manuscripts called shōgyō. This paper focuses on shōgyō of the Tōdaiji monk Sōshō (1202-1278), especially his colophons (okugaki). In examining medieval shōgyō manuscripts in general and Sōshō's in particular, modern scholars have tended to concentrate on what Markus Schiegg calls the 'assertive' aspect of a colophon, that is, a colophon that 'tells us something about the scribe and the scribal context'. Although this scholarship has contributed greatly to advancing a material-cultural approach to Sōshō's texts by situating them in their original contexts of production, little attempt has been made to explore the 'expressive' aspect of his colophons, that is, colophons expressing Sōshō's own feelings and wishes. Therefore, I compare Sōshō's assertive colophons with his expressive colophons, with an emphasis on the latter. In so doing I reveal the rich textual universe of Sōshō's colophons that defies our assumed distinction between a text and a paratext, or between the main text and its colophon that supplies information about the main text, the author, or the scribe. Sōshō's colophons often exceed these expected functions in their eloquent expression of feelings and wishes that are largely irrelevant to the main text.

Keywords: Colophon, debate, shōgyō, Sōshō, Tōdaiji

DOI: : https://dx.doi.org/10.15239/hijbs.03.01.02 
Cholar monks of medieval Japan produced a vast body of manuScripts called shōgyo 聖教, ${ }^{1}$ many of which were the products of their scholarly activities; these include notations and commentaries on sütra, Vinaya, and śāstra (shoshaku 疏釈); debate scripts (rongisō 論義草); debate records (mondōki 問答記); excerpts (shōmotsu or shömono 抄物); and written records of oral transmissions (kikigaki 聞書). ${ }^{2}$ This paper focuses on one such scholar monk from thirteenth-century Japan, the Tōdaiji 東大寺 monk Sōshō 宗性 (12021278). Throughout his life, Sōshō produced over two hundred titles covering multiple schools, topics, and genres of Buddhism. Written in kanbun kundoku style (classical Chinese with Japanese reading marks) and preserved in their original manuscript form, many of his texts have been designated as Important Cultural Properties (jüyo bunkazai 重要文化財) in Japan. ${ }^{3}$ As I have argued elsewhere, despite the extraordinary volume of his oeuvre, Sōshō has received less attention than he deserves from modern scholars partly because he 'copied' (shosha 書写) and 'excerpted' (shōshutsu 抄出), but did not author most of these texts. In other words, the copyist Sōshō's textual scholarship lacks the modern notion of 'authorship', which

1 'Sacred work' is the translation of the term shōgyō by Brian Ruppert, who is a pioneer of the study of shōgyō in English-language scholarship. See his 'A Tale of Catalogs and Colophons'.

2 Nagamura, Chüsei jiin shiryōron, 56.

3 The Tōdaiji Toshokan (Tōdaiji Library) in Nara has the original copies of Sōshō's texts, and the Shiryō Hensanjo (Historiographical Institute) at the University of Tokyo has photographed copies of most of them. The photographed copies were produced in 1968-1971. See Kuwayama, Hariu, and Takazawa, 'Tōdaiji Toshokan shozō Sōshō Shōnin kankei tenseki chōsa, satsuei', 142. According to the Agency for Cultural Affairs, 99 handscroll volumes and 347 bound books produced by Sōshō have been designated as Important Cultural Properties. See Bunkachō (Agency for Cultural Affairs), 'Tōdaiji Sōshō hitsu shōgyō narabini shōroku bon, 214 shu'. I would like to thank the Historiographical Institute for the access to the photographed copies of Sōshō's texts, as well as Professor Kikuchi Hiroki of the Historiographical Institute and Professor Minowa Kenryō of the Tokyo University for their guidance on my research on this material. 
presumes an individual 'author' who creates and therefore owns a unified body of original writings called a 'book'. ${ }^{4}$

While my larger work examines Sōshō's manuscripts as the whole, here I focus specifically on his colophons (okugaki 奥書). In examining medieval shōgyō manuscripts in general and Sōshō's in particular, modern scholars tend to concentrate on the 'assertive' aspect of a colophon, that is, a colophon that 'tells us something about the scribe and the scribal context', as defined by Markus Schiegg in his study of colophons of early medieval Europe. ${ }^{5}$ Although this scholarship has contributed greatly to advancing a material-cultural approach to Sōshō's texts by situating them in their original contexts of production, little attempt has been made to explore the 'expressive' aspect of his colophons, that is, colophons expressing Sōshō's own feelings and wishes. ${ }^{6}$ The following analysis therefore compares Sōshō's assertive with his expressive colophons, with an emphasis on the latter. In so doing it reveals the rich textual universe of Sōshō's colophons

4 I discussed this issue in my paper for the Conference on Buddhist Manuscript Cultures, Princeton University, January 2017, titled, 'The Power of Copying and the Materiality of Learning'. As Mark Dennis rightly points out in his study of Prince Shōtoku's Shōmangyō-gisho, pages 1-46 in this special issue, although the question of authorship is a valid historical inquiry, it tends to obscure the importance of material cultural approach to texts, which would require us to analyze texts in their social and historical contexts. George Keyworth's article, 'Glosses in Chinese and Japanese on Manuscript editions of Yijing's Translation of the Suvarnabhāsottama-sūtra from Dunhuang and Japan', originally presented to the manuscript conference held at Cambridge in the summer of 2018, and to be included in a volume on East Asian religious manuscripts, exemplifies such an approach by exploring the practices of reading and copying Buddhist scriptures at the Japanese Matsuo shrine during the twelfth century and after. These are the issues that I hope to explore more fully in my future work.

5 Schiegg, 'Scribes' Voices', 140. Schiegg argues that in terms of functionality, there are four different types of colophons: assertive, expressive, directive, and declarative. Following his typology, I focus here on the first two.

6 Schiegg, 'Scribes' Voices', 140. 
that defies our assumed distinction between a text and a paratext, or between the main text that is copied and its colophon that supplies information about the main text, the author, or the scribe. In fact, Sōshō's colophons often exceed these expected functions in their eloquent expression of feelings and wishes that are largely irrelevant to the main text.

\section{Sōshō’s Colophons: Formal and Contextual Quality}

In terms of formal quality, Sōshō's colophons usually follow the conventions of premodern Japanese manuscripts. Sōshō produced bound books (sasshibon 冊子本) and handscrolls (kansubon 巻子 本), both of which were common formats of premodern Japanese manuscripts. A bound book was bound on the right-hand side, while a handscroll consisted of sheets of paper glued together in sequence, creating a horizontally long piece of paper on which to write. In either format, one wrote vertically from top to bottom, and from right to left. A colophon was added at the end, and was usually indented to distinguish it from the main text.

A colophon was written at the time when the author, editor, or scribe originally created the text. Then when someone else later copied the text, the copier would usually copy the existing colophon(s) and add a new one. When a text was not copied but transmitted from one person to another (usually from a master to his disciple, as we will see later), the transmitter also added a colophon. Thus, a manuscript could bear multiple colophons written by different individuals at different times. As I have discussed elsewhere, this challenges the modern view of the author as an individual who creates and owns a unified body of text. Rather, in this case a manuscript constitutes a non-unified textual space that could involve multiple 'authors' over the course of time.

The length of a colophon varied. For example, the colophon of the

7 Sango, 'Power of Copying'. As Foucault famously asked, 'If an individual were not an author, could we say that what he wrote, said, left behind in his papers, 
Daijō-e gimon rongi shō 大乗会疑問論義抄 [Questions Discussed at the Mahāyāna Assembly] is very short for Sōshō. It simply states: ${ }^{8}$

I finished excerpting this text around the time of the monkey [i.e., between 3 p.m. and 5 p.m.] on the seventeenth day of the twelfth month of the first year of the Jōō 貞応 era [1222] at the Chūin 中 院 of Tōdaiji. [I composed this text] for this year's Daijō-e 大乗会at Hosshōji 法勝寺 and the Hokke-e 法華会 at Enshūji 円宗寺. Those who will read this later [kōran no tomogara 後覧之輩] should feel pity [awaremu beshi 可哀] [for this is poorly composed].

Thus, here Sōshō succinctly provides the date and place of composition and the reason the text was composed (i.e., to prepare for the Buddhist rituals held at Hosshōji and Enshūji in that year). Then, after concluding with a formulaic expression of humbleness, which recurs in many of his colophons, Sōshō states his disciplinary specialization ('Kegon shū' 華厳宗) and his temple affiliation ('Tōdaiji' 東大 寺), and then signs his name, followed by his secular age ('age twenty years') and his dharma age ('nine years [since being ordained]').'

Thus, even this short colophon provides quite a bit of biographical information about Sōshō. In fact, Sōshō wrote several hundred colophons, many of which are much longer than this one. Sōshō himself left no autobiography. Also, although Sōshō copied and edited many texts, he authored very few. But from his colophons we can learn quite a bit about his life and scholarship.

Sōshō was born in 1202 the son of a middle-ranking Fujiwara aristocrat and entered Tōdaiji temple at age thirteen, where he started his study of the Kegon shū, the main discipline of Tōdaiji, under the tutelage of Bengyō 弁暁 (1139-1202). In the following year, he started regularly attending the Kusha Sanjikkō 俱舎三十

or what has been collected of his remarks, could be called a work?' See Foucault, 'What is an Author?', 207.

8 Daijō-e gimon rongi shō; Hiraoka, Tödaiji Sōshō Shōnin no kenkyū narabini shiryō, vol. 1, 301-02.

9 Gerō 夏噶. See Nakamura, Kōsetsu Bukkyōgo daijiten, 1: 389c. 
講 held at Tōdaiji, that is, a public debate (rongi-e 論義会) held within the Tōdaiji temple to discuss the Abbidbarmakośa bhāsya. ${ }^{10}$ This marked the beginning of his writing career, as he began both to write down what he learned in preparing for and regularly participating in the Kusha Sanjikkō and to copy the relevant texts produced by other monks. Whereas this was a debate held within Tōdaiji, in Sōshō's time there was also a series of state-sponsored debates, such as the Daijō-e and the Hokke-e mentioned in Sōshō's colophon for the Daijo-e gimon rongi shō, that elite scholar monks would attend in seeking both academic recognition and monastic promotion. ${ }^{11}$ Throughout his life, Sōshō was repeatedly invited to these state-sponsored debates, as a result of which he eventually gained a position in the Sōgō 僧綱 (Office of Monastic Affairs) in 1241, and was later appointed head of the Kegon school in 1246 and of Tōdaiji in 1260. Given his modest birth, Sōshō's career presents an example of a scholar monk who advanced his position based largely on his own merits.

Sōshō's success as an elite scholar monk also contributed to his academic accomplishments. Not only did he advance his scholarship through copying texts to prepare for state-sponsored debates, but he also met scholar monks of other temples at these debates, such as the Enryakuji 延暦寺 monk Chien 智円 (dates unknown) as well as the Kōfukuji 興福寺 monks Kakuhen 覚遍 (dates unknown) and Ryōhen 良遍 (1196-1252). They in turn trained Sōshō in their own areas of specialty_Chien taught him Tendai 天台 teachings, while Kakuhen and Ryōhen taught him Hossō 法相 teachings-while allowing him to copy some of their texts. This is how Sōshō was able to become an interdisciplinary scholar of Buddhism.

Indeed, even a cursory look at Sōshō's scholarship reveals its incredible breadth. His manuscripts encompass the schools of Kusha

10 There are two Chinese translations of Abhidharmakośa bhāṣa: Xuanzang's (d. 664) Apidamo jushe lun (T no. 1558, 29: 1a-159b) and Paramārtha's (499-569) Apidamo jushe shilun (T no. 1559, 29: 161a-310c).

11 For further discussion of such debates, see my 'Buddhist Debate in Medieval Japan'. 
俱舎, Hossō, Tendai, Kegon, and Ritsu 律, as well as the topics of inmyō 因明 (Skt. hetu-vidyā) and the Lotus Sütra, and the genres of prayer (gammon 願文) and hagiography. Revered as an erudite scholar, Sōshō also trained many talented young monks, the most famous of whom was the Tōdaiji scholar monk Gyōnen 凝然 (1240-1321), the renowned author of the Hasshu kōyō 八宗綱要 (The Essentials of the Eight Schools). ${ }^{12}$ Thus his colophons suggest that for Sōshō, textual production was a central means of learning through which he studied not only the Kegon but also other major disciplines of Japanese Buddhism.

\section{Sōshō’s Colophons Both Assertive and Expressive}

In addition to providing rich biographical details of his life as a scholar monk, Sōshō's colophons are also a treasure trove of historical information concerning larger monastic society, and especially the intellectual, social, political, and devotional aspects of the life of elite scholar monks. For example, the colophons for the Myōbonshō 明本抄 (The Essentials of Buddhist Logic) demonstrate Sōshō's efforts to study inmyō. ${ }^{13}$ Often called 'Buddhist logic', inmyō is the study of epistemology and logical reasoning. In Sōshō's time, the Myōhonshō, composed by the renowned inmyō scholar Jōkei 貞慶 (1155-1213), a Hossō monk of Kōfukuji, was known among scholar monks as 'the most esoteric text about inmy $\vec{o}$, as Sōshō called it. ${ }^{14}$ As he himself described in his colophon for the first volume of this work, the then twenty-two

12 For more discussion of Gyōnen's life and thought, see Blum, The Origins and Development of Pure Land Buddhism; Green and Mun, Gyōnen's Transmission of the Buddha Dharma in Three Countries.

13 Hiraoka, Tōdaiji Sōshō Shōnin no kenkyū narabini shiryō, vol. 2, 460-78. Myōbonshō survives in both the handscroll and bound-book formats. The current study uses the handscroll version, which is a twelve-volume work, though the third volume is missing and there are two copies of the twelfth.

${ }_{14}$ Myōhonshō; Hiraoka, Tödaiji Sōshō Shōnin no kenkyū narabini shiryō, vol. 2,460 . 
year old Sōshō 'became the disciple of Kakuhen’ in 1225. Then, after thirty years of industrious study, Sōshō finally received 'permission to copy all thirteen volumes [of the Myöhonshō]' from Kakuhen. ${ }^{15}$

In the same colophon, Sōshō also stressed the hidden nature of the Myōhonshō by commanding that 'monks of my lineage [i.e., those who belong to Sonshōin 尊勝院, a subtemple of Tōdaiji] must conceal this text [from outsiders]'. ${ }^{16}$ To this end, Sōshō and subsequent recipients of this secret transmission signed a written agreement (Myōhonshō sōjō keijō 明本抄相承契状). An example is Sōshō's disciple Shōzen 聖禅 (b. 1202), who signed the agreement pledging to return the copy of the Myōhonshō to Sonshōin after his death. ${ }^{17}$ In this way, Sōshō limited circulation of the Myōhonshō to only the members of his own subtemple.

Originally developed as residential spaces for monks, in medieval times subtemples grew into core institutional units that, although physically located within a temple, enjoyed a considerable degree of political and economic independence. They also served as the centers of the monks' academic activities. For instance, Sonshōin, which Sōshō headed from 1246, was the center of Kegon studies. The secret transmission of the Myōhonshō thereby worked to distinguish this subtemple from others as the center of the Kegon discipline; this is the so-called shishi sojjo 師資相承—the transmission of cultural and social capital from a master to his disciple. Thus, the practice of writing and transmitting a text had the power to change both social and material reality. ${ }^{18}$

15 Myōhonshō; Hiraoka, Tödaiji Sōshō Shōnin no kenkyū narabini shiryō, vol. 2, 460 .

16 Myōhonshō; Hiraoka, Tödaiji Sōshō Shōnin no kenkyū narabini shiryō, vol. 2, 465 .

${ }_{17}$ Myōhonshō; Hiraoka, Tödaiji Sōshō Shōnin no kenkyū narabini shiryō, vol. 2, 479. It is unclear whether, strictly speaking, there was a master-disciple relationship between Sōshō and Shōzen. According to the colophons of the Myōhonshō, Sōshō and Shōzen were the same age (Hiraoka, 461-78). Also, the Honchō kōsōden 本朝高僧伝 describes Shōzen as a disciple of the Tōdaiji monk Songen 尊 玄 (dates unknown), and not Sōshō (see DBZ 102, 220). 
The colophons of the Myōhonshō accordingly reveal an important aspect of the monastic society of Sōshō's time. In addition, those written by Sōshō in particular eloquently express his feelings and wishes. This explains why, as seen in his colophon for the seventh volume of the Myōhonshō, his tends to be much longer than those of others. ${ }^{19}$ In their colophons, Kakuhen, Sōshō's teacher, and a monk named Inkan 印寛 (dates unknown; probably Sōshō's disciple or grand-disciple) simply provided one or two lines of logistical information, such as the date or place it was copied and their names and ranks. Sōshō, meanwhile, wrote as many as ten lines describing not only such details, but also how this particular volume had already been lent to another monk when he had finished copying all the other volumes the previous year, causing him to wait until this year to copy it, and how he rejoiced at the rare opportunity to form inmyō kechien 因明結縁: ${ }^{20}$

I have finally finished copying a copy [of the seventh volume of Myōhonshō]. I think of this as the memento of my study [of Buddhism] [shugaku 修学] in this life. How could it not be a good cause for the achievement of liberation [tokudatsu 得脱] in the next life? I respectfully pray that the small merit of my study will enable me to respond to [the opportunity to form] this inmyo kechien; that in the evening of the end of this life, I will finally be born in the autumn cloud of the Tusita Heaven; and that at the dawn when Maitreya [Miroku 弥勒] descends [to this world to hold] his three assemblies, I will reach the complete understanding based on wisdom [ege 慧解] on the top of the dragon-flower tree [blooming] in the spring.

18 I have discussed this issue in greater detail elsewhere. See Sango, 'Buddhist Debate and the Production and Transmission of Shōgyō in Medieval Japan'.

19 Myōhonshō; Hiraoka, Tödaiji Sōshō Shōnin no kenkyū narabini shiryō, vol. 2, 468. Kakuhen signed in 1235, Sōshō in 1255, Inkan in 1286.

20 Myōhonshō; Hiraoka, Tödaiji Sōshō Shōnin no kenkyū narabini shiryō, vol. 2, 468. Those who are familiar with Sōshō's handwriting would immediately notice that this colophon was not written by Sōshō himself. He may have asked somebody to copy it for him. 
Thus Sōshō expresses his excitement at being able to read and copy the text with the expression 'inmyō kechien'. Used by Sōshō and other transmitters of the Myōhonshō, this phrase meant forming a connection (kechien) with inmyo, which would lead to awakening or a better rebirth. Thus for Sōshō, who committed himself to the worship of the future Buddha Maitreya, inmyo kechien was the way to be reborn into Maitreya's Tusita Heaven and attend his assembly. ${ }^{21}$ In short, for Sōshō, copying the Myōhonshō was a devotional act of kechien.

Thus, Sōshō's colophons for the Myōhonshō are both assertive and expressive; not only does Sōshō explain the context of the text's production and transmission, but he also elaborately and lengthily expresses his deep feelings and wishes related to both his inmyō study and Maitreya devotion.

\section{Sōshō’s Colophons Largely Irrelevant to the Text}

Sōshō is by no means the only Buddhist author of medieval Japan who wrote expressive colophons. That said, some of Sōshō's are unusual in describing events in his life that have little to do with the texts he copied. This is exemplified, for instance, by his colophon to the Jijiron shijishō 地持論指示抄 (Excerpts of the Bosatsu jijikyō 菩 薩地持経; Ch. Pusa dichi jing; Skt. Bodhisattvabbümi sūtra), ${ }^{22}$ dated 1275.

In the eighth month of that year, Sōshō copied this text at Kasagidera 笠置寺, a temple located on Mount Kasagi, about thirtyfour miles southeast of the imperial palace in the Heian capital (present-day Kyōto), and about eight miles northeast of Kōfukuji and Tōdaiji in the old capital of Nara. In Sōshō's time, it was considered the mecca of Maitreya worship. Thus, Sōshō often went to Kasagidera

${ }^{21}$ Sōshō repeatedly mentions the rebirth in Maitreya's Tuṣita Heaven in the colophon of the Myōhonshō. See Hiraoka, Tödaiji Sōshō Shōnin no kenkyū narabini shiryō, vol. 2, 455-81.

22 T no. 1581, 30: 888a-959b. 
to leave behind the busy life of Tōdaiji and focus on his study and practice of Buddhism.

During the time he copied the Jijiron shijishō, he was at Kasagidera to mourn the death of his beloved acolyte Rikimyōmaru 力命丸, who had lived with Sōshō for several years. ${ }^{23}$ '[He] was murdered for no fault of his own. The sadness makes me speechless'. Having taken care of Rikimyōmaru's cremation and burial, the then seventy-four-year old Sōshō left Tōdaiji to stay at Kasagidera in order to hold the memorial services.

Although he was thus extremely busy and emotionally distraught during this time, Sōshō decided to copy the Jijiron shijishō for the reason that 'I had borrowed this book from my original temple [bonji 本寺; i.e., Tōdaiji], but now that I am abiding by my intention of entering the life of reclusion [inton 隠遁] [at Kasagidera], it is no longer useful. Before sending it back to my original temple, I recorded the important parts [yosho 要処] ${ }^{24}$

Thus the main event described here (i.e., the death of Rikimyōma$\mathrm{ru}$ ) has nothing to do with the content of the main text. Although the colophon still provides the date and place of its original composition, it otherwise does not serve its expected function of describing the original context of the textual production other than to say that he decided to copy the text while mourning Rikimyōmaru's death for an unrelated, rather practical reason (i.e., he wanted to return it soon to Tōdaiji). Indeed, the colophon has less to do with

23 In the elite monastic community of medieval Japan, an acolyte (chigo 稚児) often served a senior monk not only as his close attendant but also as his sexual and romantic partner (cf. Faure, The Red Thread: Buddhist Approaches to Sexuality). In fact, throughout his life, Sōshō had multiple acolytes, as evidenced by his Kindan akuji gonju zenkon seijō shō 禁断悪事勤修善根誓状抄. This is a collection of vows that Sōshō made in pursuit of good moral conduct while struggling to refrain from immoral deeds such as sexual indulgence. I have discussed this text in detail in 'Sōshō's (1202-1278) Vows to Refrain from Evils and Practice Good: A Minority Report of the Precept Revival Movement in Medieval Japan'.

${ }^{24}$ Hiraoka, Tödaiji Sōshō Shōnin no kenkyū narabini shiryō, vol. 3, 154; Jijiron shijishō. 
the text itself than with what was happening in Sōshō's personal life at the time.

For the rest of the year, Sōshō copied several more texts while remaining in reclusion at Kasagidera and mourning Rikimyōmaru's death. The colophons of all of these texts repeat the same narrative of Rikimyōmaru's unfortunate death and Sōshō's deep sorrow, which have no relation to the texts' content. Interestingly, however, read together these colophons show a process of grief. In the colophons of the texts produced in the eighth and ninth month immediately following the writing of the Jijiron shijishō, Sōshō simply related the death of Rikimyōmaru and expressed his grief. ${ }^{25}$ From the tenth month onward, however, he began to describe his act of copying itself as memorial merit-making for Rikimyōmaru, wishing that 'the merits [produced by copying this text] help him [i.e., Rikimyōmaru] achieve liberation', and that Sōshō and Rikimyōmaru would be reunited in Maitreya's Heaven. ${ }^{26}$ It is as though Sōshō had initially been so overwhelmed and consumed by his grief that he could see no purpose in copying texts (although he did so anyway), and yet gradually he came to terms with his loss and began to understand the act of copying itself as merit-making for the deceased.

Even more personal and idiosyncratic are those colophons describing Sōshō's intimate dreams; curiously, these are all colophons of the Shunka shügetsu shō 春華秋月抄, a collection of liturgical texts such as prayers and ritual pronouncements (byöbyaku 表白 or keibyaku 啓白) composed by Sōshō himself or by others. This complex text is subdivided with multiple colophons. What follows is an analysis of two sets of colophons to the first volume.

The first set consists of two colophons written in the fourth and fifth months of 1238. Both colophons are physically adjacent, and both are supposed to be related to the preceding text. The second

${ }^{25}$ Kegon soshi den; Hiraoka, Tödaiji Sōshō Shōnin no kenkyū narabini shiryō, vol. 3, 154-56.

${ }^{26}$ Kegon shū kōkun shō; Hiraoka, Tōdaiji Sōshō Shōnin no kenkyū narabini shiryō, vol. 3, 157-58; and Kegon shü kōkun shō sō; Hiraoka, Tōdaiji Sōshō Shōnin no kenkyü narabini shiryō, vol. 3, 164. 
one reads like a typical colophon with the date when Sōshō completed the text ('the first day of the fifth month of the fourth year of the Katei 嘉禎 era [1238]'), the place where he completed it ('at the Chūin of Tödaiji'), and his name. Yet the first one, written the day before the second one (the last day of the fourth month), relates the 'most auspicious dream ever' (musō no kichimu 無雙之吉夢) that he had had that night. In his dream his grandmother appeared in order to tell him the whereabouts of the 'vase in which I [i.e., his late grandmother] hid about 300-kan of money'. He rejoiced in this dream, saying, 'I should be pleased; I should be gratified; I cannot but celebrate this'. ${ }^{27}$ Thus, the second colophon was assertive while the first was expressive, having no relation to the main text itself.

In the second set of colophons, composed three months earlier, Sōshō used the same dual-colophon format. Before the straightforward colophon with the date, the place, and his name is an elaborate, expressive colophon that describes another 'most auspicious dream' he had had the previous day. It was the special day of Maitreya

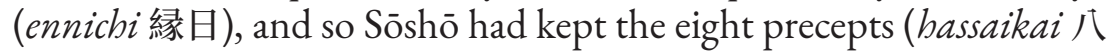
斎戒) and performed the kōshiki ritual in praise of Maitreya (Miroku Kōshiki 弥勒講式). That night, Maitreya revealed in Sōshō's dream that Sōshō would surely be blessed with the 'benefits of the two lives [nise no yaku 二世之益; i.e., this world and the next]' and 'live up to seventy-three years of age'. Upon hearing this, Sōshō found it 'very difficult to stop tears of joy'. ${ }^{28}$

Sōshō himself does not explain why he considered the colophons of this particular text, the Shunka shïgetsu shō, to be suitable for recording his auspicious dreams. Yet a thread that seems to weave these two expressive colophons together is Sōshō's interest in the 'benefits of the two lives' revealed to him through dreams by either the dead or the divine. Indeed, praying for the 'benefits of the two lives' is a major theme in the genres of prayer and ritual pronounce-

27 Shunka shügetsu shō; Hiraoka, Tödaiji Sōshō Shōnin no kenkyū narabini shiryō, vol. 2, 4.

${ }_{28}$ Shunka shūgetsu shō; Hiraoka, Tödaiji Sōshō Shōnin no kenkyū narabini shiryō, vol. 2, 1 . 
ments, on which the main text of the Shunka shügetsu shō focuses. Thus the experience of composing this text may have inspired Sōshō to have these dreams. That said, his reasons both for recording his dreams in these colophons and for separating the expressive from the assertive ones ultimately remain unknown.

Perhaps more importantly, his dream about Maitreya further reveals Sōshō's view of manuscripts, especially colophons. His description of this dream follows in its entirety: ${ }^{29}$

That evening, during the hours of the rabbit [i.e., from 5 a.m. to 7 a.m.], I dreamed the following. I was walking on the peak of a certain mountain. When I looked down, there was a big temple compound encircled by a long fence.... Then the three of us, Sōshō, Jikkō 實弘, and Jōshun 貞舜, together walked to and visited this temple compound. Thereupon, a monk came [to us] while holding a handscroll. Then, as I observed him rolling up [the scroll] from the innermost part [oku 奥] to the edge [bashi 端], I saw what looked like Sanskrit letters [bonji 梵字] written in small script. Then after rolling up [the scroll] to the edge, this monk said, 'I am showing this to you because it says “Sonshōin Minbukyō Tokugō 尊勝院民部卿得業” [i.e., Sōshō’s byname]'. ${ }^{30}$ I, Sōshō, looked at it, and thought that it indeed said so. It seemed to describe my own two lives [nise 二世] [i.e., this life and the next]. [Then] I listened to the monk read it aloud. How wonderful was the part about 'Sōshō's practice of good conduct' [zenkon 善根]! [He said that] my merit [which would lead me to enlightenment] [fukubun 福分] is not nonexistent. In terms of my life expectancy, I will live up to seventy-three years of age. Like snow, [the merit of] my strenuous study has accumulated and filled the two valleys. In this life I attend the place of rituals [i.e., I was fortunate to encounter Buddhism], and in the next life I will achieve the liberation. As I thought [to myself] that this was [indeed] what he was saying, I woke up from my dream. This was the most auspicious

29 Shunka shügetsu shō; Hiraoka, Tödaiji Sōshō Shōnin no kenkyū narabini shiryō, vol. 2, 2. Also, the draft of this colophon appears on p. 1.

30 Hiraoka, Tödaiji jiten, 271. 
dream ever. It was very difficult to stop tears of joy. The heavenly beings who protect the dharma wish to tell me that the Great Sage, Maitreya, will lead [me to his Tusita Heaven]. I deeply believe in and worship [Maitreya]. I will completely devote myself [to Maitreya] more than ever, and will never forget. I will receive the benefits of the two lives [nise no yaku] as my dream has now revealed.

To understand the full connotation of this dream, especially this mysterious manuscript revealed by the anonymous monk to Sōshō, we must remind ourselves of how a premodern Japanese handscroll was physically structured. As discussed earlier, a handscroll consisted of a number of pages arranged horizontally and glued together. On this long piece of paper, one wrote from top to bottom starting from the right edge, which the monk in Sōshō's dream called the 'edge' (bashi). ${ }^{31}$ To the opposite end-or 'innermost part'-was usually attached a jiku 軸, a thin, cylindrical-shaped piece of wood (or other material) slightly longer than the height of the scroll to facilitate its unrolling (opening) or rolling (closing). This opposite end is where one finished writing and added a colophon. Once the scroll was written or read, it would be rolled back up to close it.

In Sōshō's dream, the anonymous monk rolled the scroll back as if to indicate that he had just finished reading it. Then at a quick glance Sōshō saw 'what looked like Sanskrit letters written in small script'. ${ }^{32}$ In addition to the use of 'Sanskrit letters' (also known as siddham), the uncertainty of his language ('what looked like...') generates an aura of secrecy, thereby marking as sacred the scroll itself as well as

31 For the explanation of hashi, as opposed to oku, see Satō, Komonjogaku nyūmon, 95.

32 Originating in India and later introduced to China and Japan, bonji (Ch. fanzi) are letters used to transcribe Sanskrit words (bongo 梵語; Ch. fanyu). In China, bonji or fanzi refers to Sanskrit grammar and hermeneutics while being distinguished from its script (shittan 悉曇; Ch. xitan; Skt. siddham). In Japan, however, the term shittan was used to encompass them both, while the term bonji was used interchangeably with shittan. See Nakamura, Kösetsu Bukkyōgo daijiten, 2:1547b-c; and Nakamura et al., eds., Iwanami Bukkyō jiten, 367, 749. 
its content, which was hidden and yet were about to be revealed to Sōshō. Then the anonymous monk showed the scroll and read it aloud to Sōshō, who then realized that it revealed the 'benefits of the two lives' that he was to receive. Thus the mysterious revelation was mediated by the written text as well as the actions surrounding it (e.g., reading the scroll or rolling it back) - the object and actions that characterized the life of scholar monks such as Sōshō.

Furthermore, the anonymous monk's act of rolling the scroll back up 'from the innermost part [oku] to the edge [hashi]' suggests the symbolic significance of colophons. Okugaki, the premodern Japanese word for 'colophon,' literally means 'innermost writing' (oku-ga$k i)$, or what is written in 'the innermost part' (oku) of the scroll. The anonymous monk performatively demonstrates this unique nature of okugaki-hidden from view when the scroll is rolled up, and revealed only at the end when it is unrolled.

The English word 'colophon' in its etymology means 'summit' or 'finishing touch', which concludes all that has been written. ${ }^{33}$ Although okugaki similarly denotes conclusiveness, Sōshō's dream suggests that it also conceives a textual space differently as that which extends not only two-dimensionally (from one edge of the paper to the other edge when open) but also three-dimensionally (from the innermost to the outermost part when closed). In this textual universe, as imagined by Sōshō, okugaki is not just a secondary space to add supplementary information; rather it is an 'innermost', hidden space imbued with sanctity. ${ }^{34}$ This is where a copyist, compiler, and transmitter of a text signed their names and, in Sōshō's case, added personal details that could be either relevant or irrelevant to the text. Strictly speaking, this rich symbolism of the colophon applied only

33 For the history of the term, see Schiegg, 'Scribes' Voices', 130.

34 According to Yamasaki Makoto, in Japan, the term okugaki is often used interchangeably with daibatsu 題咙 (Ch. tiba). However, he distinguishes tiba as a unique literary convention developed during the Song dynasty, and widely popularized in the Ming (see Yamasaki, 'Janru to shite no daibatsu'). Further research is necessary to determine the meaning and usage of okugaki in Japanese literary history. 
to handscrolls, as illustrated in Sōshō's dream, but I speculate that colophons of bound books also derivatively took on this special connotation.

\section{Conclusion}

The foregoing analysis of Sōshō's colophons challenges our common understanding of a colophon as 'a short paratext containing information about the production, internal organization and storage of a particular manuscript'. ${ }^{35}$ How can we properly understand Sōshō's colophons that are not merely supplementary and secondary to the main text but that focus instead on Sōshō's own thoughts largely irrelevant to the text itself? Are his colophons paratexts or actual texts?

In his famous study of paratexts, Gérard Genette states, 'More than a boundary or a sealed border, the paratext is, rather, a threshold'. ${ }^{36} \mathrm{He}$ continues: 'It is an "undefined zone" between the inside and the outside, a zone without any hard and fast boundary on either the inward side (turned toward the text) or the outward side (turned toward the world's discourse about the text), an edge'. Thus colophons are paratextual in their mediation between texts and contexts, and in the case of Sōshō's colophons, between assertive and expressive modalities. This renders colophons both ambiguous and liminal. The 'liminality' (which etymologically means a 'threshold'), as initially conceptualized by Arnold van Gennep and Victor Turner, refers to a passage from one's previous social status and identity to a new one. ${ }^{37}$ As Turner said, 'The attributes of liminality or of liminal personae ("threshold people") are necessarily ambiguous'38 because liminality dissolves and reorients one's sense of identity while bringing about a new understanding of the world and one's place in it.

Sōshō's colophons can be understood as liminal in two senses. First, they bring Sōshō from one mode of writing (copying an exist-

\footnotetext{
35 Ciotti and Franceschini, 'Certain Times in Uncertain Places', 59.

36 Genette, Paratexts, 1-2. Emphasis in the original.

37 Van Gennep, The Rites of Passage; Turner, The Ritual Process.

38 Turner, Ritual Process, 95. Emphasis in the original.
} 
ing text) to another mode (composing a new text by expressing his own thoughts). Second, the coexistence of both his assertive and expressive engagements in his colophons generates a transformative ambiguity that Turner spoke of, as exemplified by the way in which Sōshō processed his grief for Rikimyōmaru. Initially consumed by his grief, he became more in control of it as he began to understand the act of copying itself as a way of merit-making for the dead.

Furthermore, the liminality of the textual space of colophons seems appropriate for recording dreams. Dreams in general-even mundane ones-are liminal experiences. And so, it is fitting that Sōshō recorded in his colophons his extraordinary dream encounters with beings of the other world, such as his deceased grandmother and the mysterious monk with the mysterious scroll, both of whom bestowed on him a prophecy concerning his 'benefits of the two lives' - be it the cash gift from his grandmother, longevity, or his future birth in Maitreya's Heaven.

Why did he record these dreams in his colophons? How did Sōshō expect the reader to experience his texts and his colophons in particular? Although his true intentions are ultimately unknown, one can speculate that Sōshō's records of his dreams helped legitimize him as a Buddhist author or scribe of the Shunka shügetsu shō, where prayers for the benefits of the two lives were central.

Here Genette's insight that a paratext is 'a zone not only of transition but also of transaction' is perhaps applicable; it is 'a privileged place of pragmatics and a strategy, of an influence on the public, an influence that ... is at the service of a better reception for the text and a more pertinent reading of it'. ${ }^{39}$ 'This is true not only of the colophons of the Shunka shügetsu shō, which endorsed Sōshō's textual authority, but also of those of the Myōhonshō, where Sōshō ensured a 'more pertinent reading of it' by emphasizing the significance of this text as 'the most esoteric text about inmy $\overrightarrow{0}$. Of course, in the case of the Myōhonshō, the colophons helped generate, rather than 'a better reception for the text', the text's secret transmission instead, while also providing a space for the transmitters to sign their names

39 Genette, Paratexts, 2. Emphasis in the original. 
and legitimize both their lineage as well as themselves as Buddhist scholars.

On the one hand, one must not overemphasize the applicability of Genette's and Turner's theories because medieval Buddhist authors such as Sōshō themselves may not have perceived a distinction or a 'threshold' between a text and a paratext in the same way Genette and Turner conceptualized. Also, future research is necessary to determine how prevalent Sōshō's style and view of colophons actually were. On the other hand, my analysis surely indicates a rich potential of studying colophons, not only as supplementary data, but also as the 'innermost writings' to be studied on their own terms. ${ }^{40}$

\section{Bibliography}

\section{Abbreviations}

DBZ Dai Nihon Bukkyō zensho 大日本仏教全書 [Complete Buddhist Works of Japan]. Edited by Bussho Kankōkai 仏書刊行会. 151 vols. Tokyo: Bussho Kankōkai 仏書刊 行会, 1912-1937.

T Taishō shinshu daizōkyō大正新脩大蔵経. Edited by Takakusu Junjirō 高楠順次郎 and Watanabe Kaigyoku 渡邊海旭. 85 vols. Tokyo: Taishō Issaikyō Kankōkai 大正 一切經刊行會, 1924-1934.

\section{Primary Sources}

Daijō-e gimon rongi shōo乗会疑問論義抄 [Questions Discussed at the Mahāyāna Assembly]. By Sōshō 宗性 (1202-1278) in 1222.

40 For these important methodological cautions, I would like to thank the participants of the Cambridge Conference on Manuscript Culture, Cambridge, UK, August 2018, especially Professor T. H. Barrett, who offered critical and insightful comments for my paper, and pointed me to a more contextual and nuanced approach. 
Tōdaiji: Box 103, no. 47, vol. 1; Shiryō Hensanjo: 6114/7/12. Jijiron shijishōo 地持論指示抄 [Excerpts of the Pusa dichi jing]. By

Sōshō 宗性 (1202-1278) in 1275. Tōdaiji: Box 113, no. 88, vol. 1;

Shiryō Hensanjo: 6114/7/95.

Kegon shū kōkun shō 華厳宗香薰抄 [Collection of Debate Topics for

the Thirty Lectures on the Huayanjing tanxuan ji]. By Sōshō 宗

性 (1202-1278) in 1275. Tōdaiji: Box 113, no. 8, vol. 1; Shiryō

Hensanjo: 6114/7/27.

Kegon shü kōkun shō sō 華篇宗香薰抄草 [A Draft of Collection

of Debate Topics for the Thirty Lectures on the Huayanjing tanxuan ji]. By Sōshō 宗性 (1202-1278) in 1275. Tōdaiji: Box

113, no. 6, vol. 1; Shiryō Hensanjo: 6114/7/27.

Kegon soshi den 華厳祖師伝 [Biography of the Huayan Patriarch]. By

Sōshō 宗性 (1202-1278) in 1275. Tōdaiji: Box 103, no. 97, vol. 1;

Shiryō Hensanjo: 6114/7/18.

Kindan akuji gonju zenkon seijo shō 禁断悪事勤修善根誓状抄

[Vows to Refrain from Evils and Practice Good]. By Sōshō 宗性

(1202-1278) in 1258. Tōdaiji: Box 113, no. 112, vol. 1; Shiryō Hensanjo: 6114/7/98.

Myōhonshō 明本抄 [The Essentials of Buddhist Logic]. Composed

by Jōkei 貞慶 (1155-1213) in 1212, and copied by Sōshō 宗

性 (1202-1278) in 1255. Tōdaiji: Box 103, no. 94, vols. 1-11;

Shiryō Hensanjo: 6114/7/15-17.

Myōhonshō sōjo keijō 明本抄相承契状 [Pledge of the Transmission

of the Myōhonshō], signed by Sōshō 宗性 (1202-1278) in 1255.

Tōdaiji: Box 124, no. 37, vol. 1.

Shunka shūgetsu shō 春華秋月抄 [Collection of Prayers]. By Sōshō 宗 性 (1202-1278) in 1238. Tōdaiji: Box 113, no. 123, vol. 1; Shiryō Hensanjo: 6114/7/106.

\section{Secondary Sources}

Blum, Mark Laurence. The Origins and Development of Pure Land Buddhism: A Study and Translation of Gyōnen's Jōdo Hōmon Genrushō. Oxford; New York: Oxford University Press, 2002. Bunkachō 文化庁 [Agency for Cultural Affairs]. 'Tōdaiji Sōshō hitsu shōgyō narabini shōroku bon, 214 shu’ 東大寺宗性筆聖教並抄 
録本 (二百十四種) [Shōgyō texts and excerpted texts written by the Tōdaiji monk Sōshō (214 items)]. Kuni shitei bunkazai nado database 国指定文化財等データベース [Database of National Cultural Properties and Other Relevant Information]. Accessed August 21, 2020. https://kunishitei.bunka.go.jp/heritage/ detail/201/8492.

Ciotti, Giovanni, and Marco Franceschini. 'Certain Times in Uncertain Places: A Study on Scribal Colophons of Manuscripts Written in Tamil and Tamilian Grantha Scripts'. In Tracing Manuscripts in Time and Space through Paratexts, edited by Giovanni Ciotti and Hang Lin, 59-130. Berlin, Boston: De Gruyter, 2016.

Faure, Bernard. The Red Thread: Buddhist Approaches to Sexuality. Princeton: Princeton University Press, 1998.

Foucault, Michel. 'What is an Author?'. In Aesthetics, Method, and Epistemology: Essential Works of Foucault, 1954-1984, vol. 2, edited by James D. Faubion and translated by Robert Hurley et al., 205-22. New York: New Press, 1998.

Gennep, Arnold Van. The Rites of Passage. London: Routledge \& Paul, 1960.

Genette, Gérard. Paratexts: Thresholds of Interpretation. Literature, Culture, Theory 20. Cambridge: Cambridge University Press, 1997.

Hiraoka Jōkai 平岡定海. Tödaiji jiten 東大寺辞典 [Dictionary of the Tōdaiji Temple]. Tokyo: Tōkyōdō Shuppan 東京堂書店, 1980.

— Tödaiji Sōshō Shōnin no kenkyū narabini shiryō 東大寺宗性上 人の研究並史料 [The Study of the Tōdaiji Monk Sōshō and His Texts]. 3 vols. Tokyo: Nihon Gakujutsu Shinkōkai 日本學術振興 會, 1958-1960.

Kuwayama Kōnen 桑山浩然, Hariu Kunio 針生邦男, and Takazawa Minoru 高沢実. 'Tōdaiji Toshokan shozō Sōshō Shōnin kankei tenseki chōsa, satsuei’ 東大寺図書館所蔵宗性上人関係典籍調 査・撮影 [The Examination and Photographic Reproduction of Monk Sōshō's Texts Preserved at the Tōdaiji Temple]. Tōkyō Daigaku Shiryō Hensanjo hō 東京大学史料編纂所報 [Report on the Activities of the Historiographical Institute] 6(1971): 142. Nagamura Makoto 永村眞. Chüsei jiin shiryōron 中世寺院史料論 
[A Study of Medieval Temple Documents]. Tokyo: Yoshikawa Kōbunkan 吉川弘文館, 2000.

Nakamura Hajime 中村元. Kōsetsu Bukkyōgo daijiten 広説佛教語大 辞典 [Dictionary of Buddhist Terms]. Tokyo: Tōkyō Shoseki 東 京書籍, 2001.

Nakamura Hajime 中村元, et al., eds. Iwanami Bukkyōjiten 岩波

仏教辞典 [Iwanami Dictionary of Buddhism]. Tokyo: Iwanami Shoten 岩波書店, 1989.

Green, Ronald S, and Chanju Mun. Gyonen's Transmission of the Buddha Dharma in Three Countries. Numen Book Series, Volume 159. Leiden: Brill, 2018.

Ruppert, Brian. 'A Tale of Catalogs and Colophons: The Scope of the Lineage, the Touch of the Master and Discourses of Authenticity in Medieval Shingon Buddhism'. In Scholars of Buddhism in Japan: Buddhist Studies in the 21st Century, edited by James Baskind, 49-66. Kyoto: International Research Center for Japanese Studies, 2008.

Sango, Asuka. 'Buddhist Debate and the Production and Transmission of Shōgyō in Medieval Japan'. Japanese Journal of Religious Studies 39, no. 2 (2012): 241-73.

_. 'Buddhist Debate in Medieval Japan'. Religion Compass 9, no. 7 (2015): 216-25. . 'The Power of Copying and the Materiality of Learning: The Manuscript Production of the Tōdaiji Monk Sōshō (1202-1278)'. Paper presented at the Conference on Buddhist Manuscript Cultures, Princeton University, Princeton, NJ, January 22, 2017. - 'Sōshō’s (1202-1278) Vows to Refrain from Evils and Practice Good: A Minority Report of the Precept Revival Movement in Medieval Japan'. Paper presented at the annual meeting of the American Academy of Religion, Boston, MA, November 20, 2017.

Satō Shin'ichi 佐藤進一. Komonjogaku nyūmon 古文書学入 門 [Introduction to Diplomatics]. Tōkyō: Hōsei Daigaku Shuppankyoku 法政大學出版局, 1997.

Turner, Victor W. The Ritual Process: Structure and Anti-structure. Lewis Henry Morgan Lectures, 1966. New York: Aldine De 
Gruyter, 1995.

Yamasaki Makoto 山崎誠. 'Janru to shite no daibatsu' ジャンルとして の題跋 [Afterword as a Literary Convention]. Nibon bungaku 日 本文学 [Japanese literature] 61, no. 7 (2012): 2-10. 